\title{
Comment on Roessler et al.: Short-term follow up after implantation of a cell-free collagen type I matrix for the treatment of large cartilage defects of the knee
}

\author{
Carl Haasper ${ }^{1}$ (D) \\ Received: 20 July 2015 / Accepted: 16 September 2015 /Published online: 6 October 2015 \\ (C) SICOT aisbl 2015
}

\section{Dear Editor,}

It was with great interest that I read the study entitled "Shortterm follow up after implantation of a cell-free collagen type I matrix for the treatment of large cartilage defects of the knee" by Roessler and colleagues [6]. However, as my group worked a lot with the same matrix some questions came up:

First I would like to congratulate the authors on having achieved such promising short-term results in cartilage repair. We had comparable results with the predecessor product in patellar defects which was cell based [5]. However, compared to microfracture there were no benefits detectable in our series.

Our first question is: did the authors cut the constructs' bottom or surface during implantation? With the same product we demonstrated that removing the superficial layer is essential to ensure proper ingrowth of cells into the matrix. Next, compressed hydrogels contribute better to cartilage regeneration after surface modification [3].

To avoid delamination sometimes fibrin glue is used during implantation. However, similar to our own results the group reports no beneficial effects using fibrin glue [1, 4]. Despite the lab setting this does not reflect OR reality. So, did the authors apply fibrin glue, sutures or other devices in some cases to fix the constructs during surgery?

Cell ingrowth into the scaffold is strongly dependent on the implantation technique chosen and on the hypothesis one follows in regards to the cells' origin. However, this has not been fully

Carl Haasper

carl.haasper@helios-kliniken.de; http://www.ncbi.nlm.nih.gov/ pubmed/25676840

1 HELIOS ENDO-Klinik Hamburg, Hamburg, Germany clarified yet. Why do you think surface modification is essential? Please explain the exact surface modification process performed with the scaffold referred to in Guenther et al. [3].

And finally what is the precise cut-off for distributing patients between large and small defects compared to the previously published series using the same technique $[2,7]$ ?

\section{References}

1. Efe T, Füglein A, Heyse TJ et al (2012) Fibrin glue does not improve the fixation of press-fitted cell-free collagen gel plugs in an ex vivo cartilage repair model. Knee Surg Sports Traumatol Arthrosc 20: 210-215. doi:10.1007/s00167-011-1571-4

2. Efe T, Theisen C, Fuchs-Winkelmann S et al (2012) Cell-free collagen type I matrix for repair of cartilage defects-clinical and magnetic resonance imaging results. Knee Surg Sports Traumatol Arthrosc 20: 1915-1922. doi:10.1007/s00167-011-1777-5

3. Guenther D, Oks A, Ettinger M et al (2013) Enhanced migration of human bone marrow stromal cells in modified collagen hydrogels. Int Orthop 37:1605-1611. doi:10.1007/ s00264-013-1894-5

4. Haasper C, Breitbart A, Hankemeier S et al (2008) Influence of fibrin glue on proliferation and differentiation of human bone marrow stromal cells seeded on a biologic 3-dimensional matrix. Technol Health Care 16:93-101

5. Petri M, Broese M, Simon A et al (2013) CaReS (MACT) versus microfracture in treating symptomatic patellofemoral cartilage defects: a retrospective matched-pair analysis. J Orthop Sci 18:38-44. doi:10.1007/s00776-012-0305-x

6. Roessler PP, Pfister B, Gesslein M et al (2015) Short-term follow up after implantation of a cell-free collagen type I matrix for the treatment of large cartilage defects of the knee. Int Orthop. doi:10.1007/ s00264-015-2695-9

7. Schüttler KF, Schenker H, Theisen C et al (2014) Use of cell-free collagen type I matrix implants for the treatment of small cartilage defects in the knee: clinical and magnetic resonance imaging evaluation. Knee Surg Sports Traumatol Arthrosc 22:1270-1276. doi:10. 1007/s00167-013-2747-x 